\title{
Fairness, Due Process and the NCAA: Time to Dismiss the Fiction of the NCAA as a "Private Actor"
}

\author{
Richard J. Hunter, Jr. ${ }^{1}$, John H. Shannon ${ }^{1}$ \& Laurence McCarthy ${ }^{1}$ \\ ${ }^{1}$ Stillman School of Business, Seton Hall University, U.S.A. \\ Correspondence: Richard J. Hunter, Jr., Stillman School of Business, Seton Hall University, 400 South Orange \\ Ave., South Orange, N.J., U.S.A. Tel: 1-973-761-9511. E-Mail: hunterri@shu.edu
}

Received: November 1, 2013 Accepted: November 19, 2013 Online Published: November 29, 2013

doi:10.5539/jpl.v6n4p63

URL: http://dx.doi.org/10.5539/jpl.v6n4p63

\begin{abstract}
This article raises the important question regarding the legal status of the NCAA as a "state actor" which would subject it to constitutional due process requirements. The article is written within the context of two important cases: Tarkanian and Brentwood Academy. The authors take the position that the dissenting judges in Tarkanian and the majority in Brentwood essentially "got it right" and they provide an analogy to settled Supreme Court precedents that will provide the Supreme Court with a path to bring the NCAA under the aegis of the constitution - at least as far as providing members institutions, athletic administrative personnel, and athletes a modicum of due process protections.
\end{abstract}

Keywords: state actor, color of law, due process, fourteenth amendment, company town, entanglement

\section{Introduction}

The National Collegiate Athletic Association or NCAA is a voluntary association of public and private colleges and universities that establishes competition and other rules (e.g., on recruitment, amateurism) for its members relating to intercollegiate sports. According to Marc Bianchi (2010), the NCAA was:

“... originally created to protect the health and safety of collegiate football players. President Theodore Roosevelt, who was concerned over the increasing number of football-related injuries and deaths, summoned college athletics leaders to a conference at the White House at the turn of the century to discuss reforms. On December 28, 1905, sixty-two schools met in New York City and founded the Intercollegiate Athletic Association of the United States as a discussion group and rule-making body. Five years later in 1910, the IAAUS changed its name to the National Collegiate Athletic Association." (Bianchi, 2010, p. 167).

The arena of sports has provided a valuable insight into the issues surrounding "state action" that is important in a more general discussion of the topic - especially if an actor is a notorious or powerful "nongovernmental" entity such as the NCAA. Two United States Supreme Court cases, National Collegiate Athletic Association v. Tarkanian (1988) and Brentwood Academy v. Tennessee Secondary School Association (2001), are especially relevant. A brief summary of these cases is offered here to provide the proper context to the discussion.

\subsection{Tarkanian}

The University of Nevada-Las Vegas (UNLV) was a member institution of the NCAA. A Committee of the Association investigated certain allegations of improper athletic recruiting practices by UNLV. It then issued a report which concluded that there had been numerous (38) violations of the Association's rules, including several violations (10) by the university's highly successful and ubiquitous head basketball coach, Jerry Tarkanian. The Committee proposed a series of sanctions against the university, including a 2-year period of probation. The Committee also requested UNLV to "show cause" (Nocera, 2013) why additional penalties ought not to be imposed if the university failed to remove Coach Tarkanian from its intercollegiate athletic program.

The Council of the NCAA adopted the Committee's recommendations, whereupon, after a university administrative hearing had been conducted, the president of UNLV ordered the coach to be suspended for the probation period. The UNLV hearing officer, however, expressed doubt as to the sufficiency of the evidence presented against the coach. 
Nevertheless, UNLV concluded that, given the terms of the university's membership in the NCAA, it could not substitute its own judgment as to the credibility of the witnesses. Coach Tarkanian, facing "demotion and a drastic cut in pay," brought suit in a Nevada state court against the university and a number of its officers alleging that he had been deprived of various rights, including the right to due process, under the Fourteenth Amendment to the U.S. Constitution. The NCAA was later joined as a defendant. The trial court ruled against the university and the NCAA and granted both an injunction and an award of attorney's fees pursuant to Title 42 U.S.C. Section 1988. On appeal, the Supreme Court of Nevada generally affirmed the trial court's grant of injunctive relief against the NCAA. The Supreme Court of Nevada, while narrowing the scope of the relief, expressed the view that the NCAA's actions constituted state action under the due process clause of the Fourteenth Amendment, and an action under "color of state law," under Title 42 U.S.C. Section 1983. Section 1983 states: "Every person who, under color of any statute, ordinance, regulation, custom, or usage, of any State or Territory...., subjects, or causes to be subjected, any citizen of the United States or other person within the jurisdiction thereof to the deprivation of any rights, privileges, or immunities secured by the Constitution and laws, shall be liable to the party injured in an action at law, suit in equity, or other proper proceeding for redress...." It also concluded that the fact-finding procedures used by the NCAA violated due process.

In a 5-4 decision, the United States Supreme Court reversed the decision of the Nevada Supreme Court and held that the coach could not challenge the NCAA on constitutional grounds for allegedly violating his constitutional rights. The Supreme Court ruled that the NCAA's participation in the events that led to Tarkanian's suspension by UNLV did not constitute "state action" prohibited by the Fourteenth Amendment, and was not performed "under color of law" within the meaning of Section 1983.

The language of Tarkanian is particularly insightful. The Court's majority noted that:

"Embedded in our Fourteenth Amendment jurisprudence is a dichotomy between state action, which is subject to scrutiny under the Amendment's Due Process Clause, and private conduct, against which the Amendment affords no shield, no matter how unfair that conduct may be. As a general matter the protections of the Fourteenth Amendment do not extend to "private conduct abridging individual rights.'" (Tarkanian, 1988, p. 190).

The Court continued: "Careful adherence to the 'state action' requirement preserves an area of individual freedom by limiting the reach of federal law" and avoids the imposition of responsibility on a State for conduct it could not control. When Congress enacted Section 1983 as the statutory remedy for violations of the Constitution, it specified that the conduct at issue must have occurred "under color of" state law; thus, liability attaches only to those wrongdoers "who carry a badge of authority of a State and represent it in some capacity, whether they act in accordance with their authority or misuse it." The Court added: "Misuse of power, possessed by virtue of state law and made possible only because the wrongdoer is clothed with the authority of state law, is action taken 'under color of' state law.'" (Tarkanian, 1988, pp. 190-191).

\subsection{Brentwood Academy}

The Tennessee Secondary School Athletic Association (TSSAA) is a not-for-profit membership corporation organized to regulate interscholastic sport among public and private high schools in the state of Tennessee. Although there was no requirement for Association membership, almost all the state's public high schools (about 290 such schools, or 84 percent of the TSSAA's voting membership) and 55 private schools were members. Under the bylaws of the Association, each member school was represented by its principal or by a faculty member, who had a vote in selecting members of the TSSAA's governing bodies (the Board of Control and the Legislative Council) which were chosen from eligible principals, assistant principals, and superintendents. Half of the governing bodies' meetings were held during official school hours. Public schools largely provided for the financial support of the Association. In previous years, Tennessee's state board of education had expressly designated the TSSAA as "regulator" of interscholastic athletics in Tennessee's public schools. Although these terms had been deleted in 1996, members of the state board continued to be assigned to serve as members of the TSSAA's two governing bodies; several of the TSSAA's employees were treated as state employees to the extent that they were deemed eligible for membership in Tennessee's state's retirement system. The TSSAA enforced rules and regulations that had been previously reviewed and approved by the state board. Further, the state board allowed students to satisfy the board's physical education requirement by taking part in interscholastic athletics sponsored by the TSSAA.

In 1997, the TSSAA's board of control found that a private parochial high school that belonged to the TSSAA had violated a TSSAA rule that prohibited "undue influence" in recruiting athletes for its program. The TSSAA accordingly placed the school's athletic program on probation for 4 years, and declared the Brentwood Academy's 
football and boys' basketball teams ineligible to compete in state playoffs for two years. The Association also imposed a $\$ 3,000$ fine. Brentwood Academy objected to the procedures employed on "due process" grounds and claimed that enforcement of the rule was state action and a violation of the Fourteenth Amendment to the U.S. Constitution. Brentwood Academy sued the TSSAA and its executive director in the United States District Court for the Middle District of Tennessee under 42 U.S.C. Section 1983. The District Court ruled that the TSSAA was in fact a "state actor" under Section 1983 and the Fourteenth Amendment. The District Court entered summary judgment for the school and enjoined the TSSAA from enforcing the rule. The United States Court of Appeals for the Sixth Circuit, however, reversed the district court and vacated the injunction. In so doing, the Sixth Circuit expressed the view that the TSSAA was not a state actor, had no "symbiotic relationship" with the state, and had not engaged in a traditional and exclusive public function.

On certiorari, the United States Supreme Court reversed the judgment of the Seventh Circuit Court of Appeals and remanded the case to the trial court for further proceedings. In an opinion authored by Justice Souter, who had been in the four-justice minority in Tarkanian, the United States Supreme Court held that the TSSAA had engaged in state action, for purposes of the Fourteenth Amendment, when it enforced the rule against the member school. The Court stated that the TSSAA's "nominally private character" was overborne by a "pervasive entwinement" of state school officials in the TSSAA's structure. Perhaps more importantly, the United States Supreme Court ruled that there was no substantial reason to claim unfairness in applying constitutional standards to the TSSAA.

It is important to understand the factual circumstances under which the Supreme Court was able to distinguish Brentwood Academy v. Tennessee Secondary School Athletic Association from Tarkanian: most schools (both private and public) in Tennessee belonged to the Association; the governing body of the Association was composed of mainly "public" schools; meetings were held during regular school hours; employees of the Association were eligible to join the state retirement system; and the TSSAA was funded essentially from the revenues generated from the regulated sports themselves. Thus, the Supreme Court determined that the Association was so entwined with the state that its action could legitimately and constitutionally attributed to the state and thus be considered as state action — at least as far as providing due process to Brentwood Academy.

On its face, the decision in Brentwood Academy is noteworthy since it flows most naturally from the arguments expressed by the minority in Tarkanian, who would have applied state action standards, and thus "due process" requirements, to the NCAA. This paper argues that the Supreme Court "got it right" in Brentwood Academy, and that it should adopt and expand upon the standard established in Brentwood Academy as it goes forward in determining the issue of "state action" in the area of collegiate sports - at least as it would be prospectively applied to enforcement proceedings carried out by the NCAA. We will argue that this interpretation is in reality not a new or novel one; rather, it is a logical and practical extension of earlier decisions of the Supreme Court which focused on the "involvement" of the state with an otherwise private entity. The fact that this theory had formed the basis of the opinion of the four judges in the minority in Tarkanian would simply indicate that the time had come for a reappraisal of the majority's and the minority's views - especially taking into account an essential fairness argument. (Hunter \& Alexander, 2007).

\section{Fourteenth Amendment Implications}

The precise language of the Fourteenth Amendment, quoted at the outset of this article, makes it clear that the Amendment applies only to governmental action. Under an interpretation from the United States Supreme Court in the so-called Civil Rights Cases (1883), the acts of private individuals have been held not to fall within the prohibitions of the Fourteenth Amendment. Thus, state action would be found only when one of the three branches of the federal government—-legislative, judicial, or executive — or of a state government, through a process called "incorporation," whereby the United States Supreme Court has determined that various provisions of the Bill of Rights are applied to (incorporated against) the States (Hunter \& Lozada, 2010), or their political subdivisions has deprived an individual of "life, liberty or property without due process of law."

\section{1 "Due Process"}

What is "due process" and why is it so important? Due process may be best defined in one word- "fairness." The requirement of due process extends to the substance of an action and also to the procedures employed in guaranteeing individuals their due process rights. In the United States, we look to both federal and state constitutions, statutory law, and judicial precedents found in case law to provide the standards for "fair treatment" of persons or citizens by federal, state, and local governments. These "standards" have been come to be known collectively as due process. When a person has been judged to have been treated unfairly by the government, that individual is said to have to have been deprived of or denied due process. Minimally, due process includes the following two elements: 
- $\quad$ Notice of any potential violation;

- Conducting a hearing to determine the facts and mete out any appropriate judicial or administrative penalty or sanction.

The "hearing" requirement of due process is often the main area of judicial contention. A hearing is defined broadly as a proceeding wherein an issue of law or fact is adjudicated and evidence is presented to help determine the facts at issue. In Cleveland Board of Education v. Loudermill (1984), the United States Supreme Court stated: "Under the Due Process Clause, an individual must be given an opportunity for a hearing before he is deprived of any significant property interest...." The hearing requirement may be that of a formal trial in a criminal matter. In other matters, a hearing may resemble a trial in that a hearing may be held publicly and involve the clash of opposing parties. A hearing may also be differentiated from a more formal trial in that a non-judicial hearing may feature more relaxed standards of evidence and procedure, or may take place in a variety of less formal settings or before a broader range of competent authorities.

In the United States, hearings fall into three broad categories: judicial, administrative, and legislative. (Model State Administrative Procedure Act, 1981). Judicial hearings take place within a formal judicial process. Administrative hearings deal with finding of fact, matters of rule making, and the adjudication of individual cases based on established rules, regulations, and procedures enacted by a variety of administrative bodies, boards, commissions, or agencies. Legislative hearings occur at both the federal and state levels and are generally conducted in order to find facts, establish a legislative record (called "legislative history"), seek testimony from competent witnesses, or generally elicit public opinion on a wide variety of issues of public concern.

An important analysis made by the late Judge Henry Friendly (1975) denotes certain procedural safeguards in both content and relative priority relating to due process rights, which may include:

1. An unbiased tribunal.

2. Notice of the proposed action and the grounds asserted for it.

3. Opportunity to present reasons why the proposed action should not be taken.

4. The right to present evidence, including the right to call witnesses.

5. The right to know opposing evidence.

6. The right to cross-examine adverse witnesses.

7. A decision based exclusively on the evidence presented.

8. Opportunity to be represented by counsel.

9. Requirement that the tribunal prepare a record of the evidence presented.

10. Requirement that the tribunal prepare written findings of fact and reasons (conclusions of law) for its decision. (Generally, Katyal \& Schultz, 2012).

As a result of a series of important Supreme Court cases, the reaches of the Fourteenth Amendment were found to apply to conduct of government officials who were acting in their "official capacities." The term "color of law" was applied, even though the specific action of the official was illegal or forbidden by law. In Ex parte Virginia (1879), for example, the actions of a state jury commissioner who discriminated against blacks in the process of jury selection was held to be "state action" even both though state and federal law barred such discrimination. Later, in Screws v. United States (1945), a state police officer who beat a prisoner to death in an effort to secure a confession to a crime (or, in another case, one who might stand-by while someone else beats a prisoner to death), implicates "state action" because the police officer, acting in his official capacity, has clearly deprived the prisoner of life without due process of law.

Under this analysis, for example, a government-created corporation (Amtrak), authorized by a special federal statute for "the furtherance of governmental objectives," with the President having the authority to appoint a majority of its directors, is a "part of the government for purposes of the First Amendment," even though the authorizing statute had disclaimed this fact. Thus, Amtrak fell within the definition of a government agency which must accord individual due process rights. (Lebron v. National Railroad Passenger Corp. (Amtrak), 1995).

In other cases, the United States Supreme Court has found that activities undertaken by private persons or organizations that are "traditionally the exclusive prerogative of the State" may be considered as "state action" as well. The Court has used such terms as "public" or "governmental" to characterize such activities. 
For example, in two cases, the United States Supreme Court held that conducting elections is exclusively a state function and thus invalidated racial discrimination by non-governmental groups (political organizations or parties) who exercised effective control over the selection process of candidates in a primary or pre-primary process. In Smith v. Allwright (1944), the Supreme Court held that the Texas Democratic Party could not constitutionally exclude African-Americans (then called Negros) from voting in a primary election from which the Democratic Party nominee for the general election would be chosen. In 1953, in Terry v. Adams (1953), the Supreme Court held that the Jaybird Democratic Organization in Texas could not exclude African-Americans from a pre-primary election process when the winner of this contest almost always ran unopposed in both the primary and general elections. Thus, a private party, exercising an important governmental function, would be considered as a state actor.

\subsection{State Involvement in Essentially Private Actions}

Since the 1960s, the United States Supreme Court has decided a large number of cases where the government, while not acting as a principal, has nonetheless required or significantly encouraged specific acts of discrimination - found to be in violation of the Fourteenth Amendment's Equal Protection Clause. At the outset, it should be recognized that the determination of whether state action has or has not occurred is not one that can be decided by rote; rather, under the analysis found in Burton v. Wilmington Parking Authority (1961), it requires a careful case-by-case determination.

In August of 1958, William H. Burton, an African-American, entered the Eagle Coffee Shoppe, a restaurant that was leasing space within a parking garage operated by the Wilmington Delaware Parking Authority. Burton was denied service solely on the basis of his race. The Parking Authority is a tax-exempt, private corporation that was created by legislative action of the City of Wilmington for the purpose of operating the city's parking facilities. The Authority's projects were partially funded by tax contributions from the city of Wilmington. The Parking Authority provided the restaurant with heating and gas services and maintained the premises at its own expense. The Eagle Coffee Shoppe paid a monthly rental fee to the city, and thus was in the position of a lessee. Burton filed suit seeking an injunction in order to prevent the restaurant from operating in a racially discriminatory manner, basing his argument that doing so violated the Equal Protection Clause of the Fourteenth Amendment. At trial, a lower state court granted the injunction but the order granting the injunction was reversed on appeal by the Delaware Supreme Court. The United States Supreme Court was asked to consider this question: Did the Eagle Coffee Shoppe's refusal to serve Burton constitute a violation of the Equal Protection Clause of the Fourteenth Amendment of the United States Constitution?

The question was answered in the affirmative in a 6-3 decision authored by Justice Tom C. Clark. The Supreme Court concluded that the restaurant, as a recipient of assistance by the Parking Authority, clearly benefited from the city's aid and "constituted a physically and financially integral and, indeed, indispensable part of the State's... plan to operate its project as a self-sustaining unit." As such, the Court found that the state of Delaware, through the actions of its Parking Authority, had "made itself a party to the refusal of service." The action was no longer that of a private individual or entity but had been transformed into one of the state through the operation of these facts.

In Peterson v. City of Greenville (1963), the Supreme Court decided that when a city ordinance required racial segregation in restaurants, the actions of a private restaurant owner who caused ten African-Americans to be prosecuted for unlawful trespass was held to be state action. In Lombard v. Louisiana (1963), three Negro students and one white student, entered a store in New Orleans, La., and sat at a lunch counter which was reserved for "white" people. The students requested service, which was refused. The students refused to leave the establishment, having been asked to do so by the store manager. The students were convicted for violating the Louisiana Criminal Mischief Statute, which makes it a crime to refuse to leave a place of business after being ordered to do so by the person "in charge of" the premises. In this case, no state statute or city ordinance required racial segregation in restaurants. However, both the Mayor and the Superintendent of Police had announced publicly that such "sit-in demonstrations" would not be permitted. The United States Supreme Court, by a vote of 8-1, held that the convictions violated the Equal Protection Clause of the Fourteenth Amendment and determined that the actions of the restaurant manager amounted to state action.

In a series of important cases relating to the enforcement of racially restrictive covenants, the Supreme Court was called upon to rule on issues relating to state enforcement of a private racial covenant. Could a court be enlisted to enjoin black persons who had purchased property from a white homeowner from taking possession of that property or award monetary damages against a white seller to the other signatories of the restrictive covenants who had failed to include the covenant in their deed? Would this constitute "state action"? The seminal case was Shelley v. Kraemer (1948). 
The Kraemer's were a white couple who owned a residence in a Missouri neighborhood that was governed by a racially restrictive covenant. The Shelley's were a black couple who moved into the Kraemer's neighborhood. The Kraemer's went to court to enforce the restrictive covenant against the Shelley's. The United States Supreme Court ruled unanimously (with six judges participating) that state courts could not constitutionally prevent the sale of real property to blacks even if that property is covered by a racially restrictive covenant. (E.g., Krotoszynski, 1995).

The Court concluded that standing alone, a racially restrictive covenant entered into by private parties violates no constitutionally protected rights. However, the enforcement by a state court through the issuance of an injunction would constitute state action in violation of the 14th Amendment. A similar result was reached in Barrows v. Jackson (1953).

Petitioners sued respondent in a California state court to recover damages for an alleged breach of a racially restrictive covenant. The case arose when owners of residential estates in a neighborhood in Los Angeles entered into a mutual covenant restricting the use and occupancy of the property to persons of the white or Caucasian race. The covenant also required that signers to the covenant incorporate this restriction in all future transfers of land. For breaching the covenant in both respects, an action for damages was brought against the defendant by the signers of the restrictive covenant. No action was taken against the non-Caucasian occupants. The state courts decided in favor of the defendant and awarded \$1,600 in damages. However, in an opinion by Justice Minton, relying upon the principles announced in Shelley, six members of the Supreme Court held that a restrictive covenant could not be enforced in a suit for damages against a co-covenantor who actually broke the covenant. Justice Minton quoted from Shelley: "The Constitution confers upon no individual the right to demand action by the State which results in the denial of equal protection of the laws to other individuals. ..." (Shelley v. Kraemer, 1948, p. 22).

State action may also be found where a state regulatory agency affirmatively approves a practice of a "regulated" business. For example, in Public Utilities Commission of the District of Columbia v. Pollak (1952), a street railway company located in the District of Columbia, whose service and equipment were subject to regulation by the Public Utilities Commission of the District of Columbia, received and amplified radio programs through loudspeakers in its streetcars and busses. The programs consisted generally of $90 \%$ music, $5 \%$ announcements, and 5\% commercial advertising. After conducting an investigation and holding a series of public hearings, the Commission concluded that the radio service was not inconsistent with "public convenience, comfort and safety." The Commission thus permitted the broadcasts to continue despite protests of some passengers that their constitutional rights under the First Amendment had been violated. The Supreme Court was called upon to resolve a number of constitutional questions.

At the outset, the Court decided the threshold issue and held that neither the operation of the radio service nor the action of the Commission permitting its operation was precluded by any provision of the United States Constitution. The Court then found it appropriate to examine what restrictions, if any, the First and Fifth Amendments might place upon a regulated business under the facts of this case, assuming that the action of the street railway company in operating the radio service, taken together with the action of the Commission in permitting such operation, amounts to sufficient state action to make the First and Fifth Amendments applicable.

The Court reiterated that the First and Fifth Amendments apply to and restrict only the federal government and generally not private persons. However, finding a sufficiently close relationship between the District of Columbia and the street railway company required the Court to now consider whether it would be appropriate to apply the First and Fifth Amendments. In so doing, the Court relied upon the fact that the Commission, an agency authorized by Congress, had ordered an investigation of the radio service and, after formal public hearings, ordered its investigation dismissed on the ground that the public safety, comfort, and convenience had not been impaired.

\subsection{Are There Any Limits?}

There are, however, limitations to the "relationship" doctrine. In Jackson v. Metropolitan Edison (1974), the fact that a practice or action had been filed with or accepted by a regulatory agency (in this case, an action terminating electrical service without notice) did not make the practice itself state action even though the agency was heavily regulated by the state. Justice Rehnquist reiterated that private actions remain "immune from the restrictions of the Fourteenth Amendment." Likewise, as long as the state does not require or significantly encourage a practice, the fact that an extensively regulated business engages in a practice does not convert that practice into state action. (Blum v. Yaretsky, 1982; Rendell-Baker v. Kohn, 1982).

Similarly, in Moose Lodge v. Irvis (1972), the United States Supreme Court held that despite the fact that a business is licensed by the state or that it receives state services (such as electricity or water or police or fire protection) does not necessarily make its conduct state action. In a 6-to-3 decision, the Court held that the Moose 
Lodge's refusal to serve food and beverages to Irvis because he was black did not violate the Fourteenth Amendment. The Court reiterated that the state action doctrine did not necessarily apply to all private entities that received benefits or services from the government; otherwise, Justice Rehnquist reasoned, all private associations that received electricity, water, and fire protection would be subject to state action analysis. The Court found that the Moose Lodge was in the main "a private social club in a private building," and thus its actions were not subject to the Equal Protection Clause of the Fourteenth Amendment.

However, on the other side of the argument, there may be circumstances where the Court might find such involvement or a relationship so as to trigger due process requirements. One such case involved racial discrimination in housing. The California Legislature, during the period 1959-1963, had enacted several statutes essentially banning racial discrimination in housing. In 1964, pursuant to an initiative and referendum, a process which had gained great popularity in California and other jurisdictions as a way for "ordinary citizens" to weigh in on matters of public policy when they disagreed with actions taken by their legislative or judicial branches, Art. I, Section 26 was added to the California state constitution. It provided that neither the State of California nor any agency thereof "shall deny, limit or abridge, directly or indirectly, the right of any person, who is willing or desires to sell, lease or rent any part or all of his real property, to decline to sell, lease or rent such property to such person or persons as he, in his absolute discretion, chooses." The constitutional provision was challenged on the basis of the Equal Protection Clause of the Fourteenth Amendment of the United States Constitution. In Reitman v. Mulkey (1967), the Supreme Court ruled that where a state constitutional amendment had repealed existing anti-discrimination in housing statutes and had prevented the state legislature from regulating the sale or lease of residential property in the future, the state was in fact encouraging racial discrimination. Thus, the Supreme Court determined that the California amendment had been properly challenged on the basis of a Fourteenth Amendment, state action analysis.

What does this rendition of the history of the Supreme Court cases in relation to a finding of state action have to do with whether an organization such as the NCAA can proceed to enforce a rule or regulation in the absence of providing due process protections? Clearly, the NCAA is not the government; neither is it a government agency such as Amtrak; nor does it use a court to enforce any of its edicts or penalties as was the issue in Shelley v. Kraemer; nor is the NCAA an organization engaged in an activity that is "traditionally the exclusive prerogative of the State" under either Smith or Terry. Is there any chance, then, that the NCAA might still be subjected to "due process considerations"?

An insight might be found in the Court's analysis of a private corporation operating essentially a "company town." We have analogized this "only game in town" analysis as it applies to the world of sports, more specifically to the actions of the NCAA, which occupies an effective dominant position (some might say a "monopoly") with regards to intercollegiate athletics in the United States. Thus, based upon the history of the creation of the NCAA, and the enormous power it wields over intercollegiate athletics in the United States, it might be "fair" to ask: Is it important to legally recognize that the NCAA is an integral part of the athletic programs at scores of private and public universities and colleges like UNLV and that NCAA rules operate under the aegis of a state university to enforce its rules? In more direct terms, is the NCAA so entwined with the state so as to convert its actions into state action?

A second theory, perhaps less esoteric and more orthodox, would hold that joint action by a private party (the NCAA) with the government under an enhanced application of the "entwinement doctrine" might be sufficient to characterize an otherwise private party as a "state actor" for purposes of the Fourteenth Amendment. We shall discuss this more standard or traditional argument first.

\section{The "Entwinement Argument Revisited and Repositioned": A Focus on the Dissenters in Tarkanian}

The minority in Tarkanian had stated the obvious: UNLV, a public university, is clearly a state actor, and that the suspension of Jerry Tarkanian, a public employee by UNLV, was state action. Thus, UNLV owed Coach Tarkanian some measure of due process in its effort to suspend or fire him. However, they framed the issue as to the NCAA in different terms from that of the majority: "The question here is whether the NCAA acted jointly with UNLV in suspending Tarkanian and thereby also became a state actor." Writing for the four justice minority, Justice White responded: "I would hold that it did." (Tarkanian, 1988, p. 199).

As the majority in Tarkanian noted, in a "typical case raising a state-action issue, a private party has taken the decisive step that caused the harm to the plaintiff." In this case, however, the final act or "decisive step" that caused the harm to Tarkanian was committed, not by a private party, but by a party conceded to be a state actor-UNLV.

Justice White cited two cases, Adickes v. S. H. Kress \& Co. (1970) and Dennis v. Sparks (1980), where the Court was confronted by the question whether a private party could be held to be a state actor where the final or decisive 
act was carried out by a state official. In both cases, the Supreme Court held that the private parties could be found to be state actors, if they were "jointly engaged with state officials in the challenged action."

Justice White stated that it was clear that the NCAA had in fact acted jointly with UNLV in suspending Tarkanian. First, Coach Tarkanian had been suspended for violations of NCAA rules, which UNLV had embraced and committed itself to enforce in its association agreement with the NCAA. Justice White noted that the Nevada Supreme Court had found that "[a]s a member of the NCAA, UNLV contractually agrees to administer its athletic program in accordance with NCAA legislation." It is clear that NCAA "enforcement procedures are an essential part of the intercollegiate athletic program of each member institution."

Second, the NCAA and UNLV also agreed that the NCAA would conduct the hearings concerning violations of its rules - essentially relegating to the NCAA an "important state function," as the Court had found in Terry v. Adams (21953). Although UNLV had conducted its own investigation into the recruiting violations alleged by the NCAA, NCAA procedures provide that the NCAA Committee on Infractions "determine[s] facts related to alleged violations," subject to an appeal to the NCAA Council. As a result of this agreement, the NCAA conducted the hearings that the Nevada Supreme Court held violated Tarkanian's right to procedural due process.

Third, the NCAA and UNLV agreed that the "findings of fact" made by the NCAA at the hearings it conducted would be binding on UNLV - again, implicating Terry. By accepting membership in the NCAA, UNLV did more than merely "promise to cooperate in the NCAA enforcement proceedings." (Tarkanian, 1988, p. 196.) UNLV agreed to accept the NCAA's "findings of fact as in some way superior to [its] own." By the terms of UNLV's membership in the NCAA, the NCAA's findings of fact were indeed final and dispositive and not subject to further review by any other body. Justice White concluded that it was for that reason that UNLV suspended Coach Tarkanian, despite concluding that many of those findings were erroneous. (Tarkanian, 1988, p. 102).

Finally, Justice White noted that the five-justice majority relied extensively on the fact that the NCAA and UNLV were in fact adversaries throughout the proceedings before the NCAA. While the majority provided a detailed description of UNLV's attempts to avoid the imposition of sanctions by the NCAA, this did not necessarily undercut the agreement itself which required UNLV to terminate Coach Tarkanian or face additional sanctions.

Justice White placed great emphasis on the fact that, as the majority stated in conclusion, "[i]t would be ironic indeed to conclude that the NCAA's imposition of sanctions against UNLV—-sanctions that UNLV and its counsel, including the Attorney General of Nevada, steadfastly opposed during protracted adversary proceedings - is fairly attributable to the State of Nevada." He agreed, but noted that had UNLV refused to suspend Tarkanian, and the NCAA responded by itself imposing sanctions against UNLV, it would be hard to find any state action that harmed Coach Tarkanian. But, as noted by Justice White, that was not this case. In this case, UNLV did suspend Coach Tarkanian, and it did so because UNLV had embraced the NCAA rules governing conduct of its athletic program and as a result had adopted the results of the hearings conducted by the NCAA. Under these facts, the four-justice minority composed of Justices White, Brennan, Marshall, and O'Connor would have found that the NCAA had at a minimum "acted jointly" with UNLV and therefore was a state actor. Thus, the opinion of the minority in Tarkanian was factually and legally consistent with a line of Supreme Court precedents emanating from Burton $v$. Wilmington Parking Authority (1961), Terry v. Adams (1953), and in line with and may have presaged the later opinion in Brentwood Academy (2001).

In sum, "it was the NCAA's findings that Tarkanian had violated NCAA rules, made at NCAA-conducted hearings, all of which were agreed to by UNLV in its membership agreement with the NCAA, that resulted in Tarkanian's suspension by UNLV. On these facts, the NCAA was 'jointly engaged with [UNLV] officials in the challenged action,' and therefore was a state actor."

\section{One Final Argument: The "Company Town" or "Only Game in Town" Analogy}

At a point in the decision in Tarkanian, the majority addressed the issue relating to the power that the NCAA had exercised throughout the entire period of its controversy with Coach Tarkanian. (For a statement of possible sanctions that may be imposed by the NCAA, see Appendix I.) Responding to the fact that the NCAA was in reality the "only game in town - perhaps most especially with regard to collegiate basketball and its annual ritual called "March Madness" - the Court noted: "The university's desire to remain a powerhouse among the Nation's college basketball teams is understandable, and non-membership in the NCAA obviously would thwart that goal. But that UNLV's options were unpalatable does not mean that they were nonexistent." Indeed, one option discussed in the Tarkanian controversy was to "Pull out of the NCAA completely on the grounds that you will not execute what you hold to be their unjust judgments." Was this option really tenable? Or, considering the enormous power of the NCAA, both in terms of money and prestige, did UNLV really have any choice? It should be 
recognized that the NCAA itself had no power to force UNLV to terminate Coach Tarkanian. However, if the University chose not to do so, the consequences could be catastrophic. NCAA rules provide:

"Upon finding that misconduct by an employee of a member institution caused NCAA rules to be violated, the Committee may require the member to "show cause" why:

"(i) a penalty or an additional penalty should not be imposed if, in the opinion of the Committee (or Council), it does not take appropriate disciplinary or corrective action against athletic department personnel involved in the infractions case, any other institutional employee if the circumstances warrant, or representatives of the institution's athletic interests; or

"(ii) a recommendation should not be made to the membership that the institution's membership in the Association be suspended or terminated if, in the opinion of the Committee (or Council), it does not take appropriate disciplinary or corrective action against the head coach of the sport involved, any other institutional employee if the circumstances warrant, or representatives of the institution's athletic interests."

As has been demonstrated, the United States Supreme Court generally has not found that private conduct to be a "public" or "governmental" function, subjecting that conduct to due process standards. However, there was one unusual instance where the Court was willing to cross the line and subject private conduct to the due process requirements of the Fourteenth Amendment. Could an analogy to Marsh v. Alabama (1946) provide a different perspective than prior case rulings that had rejected the application of "state action" to otherwise private conduct? In a larger sense, considering the enormous power that the NCAA effectively wields, is it time for the American court system to apply due process requirements - at least to NCAA enforcement actions?

Grace Marsh, a Jehovah's Witness, attempted to distribute religious literature on the sidewalk near a post office located in Chickasaw, Alabama. The town of Chickasaw was owned and run by the Gulf Shipbuilding Corporation and was not a public municipality. The company had posited the following notice in stores which the corporation also owned: "This Is Private Property, and Without Written Permission, No Street, or House Vendor, Agent or Solicitation of Any Kind Will Be Permitted." Despite this fact of essentially private (corporate) ownership, the town exhibited most of the same characteristics as would any other town. Marsh was informed that she was on private property and was told to stop the distribution of her religious material by a representative of Gulf Shipbuilding. Marsh refused. She was arrested, tried, and convicted of trespass.

The Supreme Court considered the following question: Did the State of Alabama violate Marsh's rights under the First and Fourteenth amendments when Gulf Shipping (Chickasaw) refused to allow her to distribute religious material in the privately owned town of Chickasaw?

In an opinion by Justice Hugo L. Black, the Court in a 5-3 decision found that there was no significant difference between the relationship between Chickasaw and private citizens and the relationship between any other town and its citizens. As such, the Supreme Court employed a balancing test, weighing private property rights against an individual's right to free speech - a right that was guaranteed under the United States Constitution. The Court ruled in Marsh's favor and applied constitutional protections.

However, thirty years later, the Court was not willing to extend the "company town" argument to a shopping center on the grounds that a shopping center "was not the functional equivalent" of a municipality because it did not possess all of the attributes of a town. In Hudgens v. NLRB (1976), the Court noted: "The closest decision in theory, Marsh v. Alabama, involved the assumption by a private enterprise of all of the attributes of a state-created municipality and the exercise by that enterprise of semi-official municipal functions as a delegate of the State. In effect, the owner of the company town was performing the full spectrum of municipal powers and stood in the shoes of the State. In the instant case there is no comparable assumption or exercise of municipal functions or power." (Hudgens, 1976, pp, 519-520). The Court continued: "We hold that there has been no such dedication of [Lloyd's] privately owned and operated shopping center to public use as to entitle respondents to exercise therein the asserted First Amendment rights. ..." (Hudgens, 1976, p. 520).

The United States Supreme Court has also refused to apply due process to a monopoly business because the "supplying of utility services is not traditionally the exclusive province of the state." (Jackson v. Metropolitan Edison, 1974); and to a highly regulated business such as a nursing home or a specialized private school almost completely funded and subject to extensive state regulation by the state, again on grounds that these types of business are not "the exclusive province of the state." (Blum v. Yaretsky, 1982); Rendell-Baker v. Kohn, 1982). 


\section{The Question Remains: Is the NCAA the Functional Equivalent of a "Company Town" or the "Only Game in Town"? And, Perhaps More Importantly: What Is the Right Thing to Do?}

According to the website of the NCAA (2013), "The NCAA is a member association composed mostly of higher education institutions. Each member school is able to choose a level of competition that best fits its mission. Competition is offered in Division I (the largest programs that provide the most athletically related financial aid for student-athletes), Division II (limited financial aid) and Division III (no athletically related financial aid)."

As of 2013, there are 1,066 active member schools in the NCAA membership-340 in Division I, 290 in Division II, and 436 in Division III. The NCAA also contains 95 member conferences in all three divisions. (See Appendix II.) Overall membership - including schools, conferences, and related associations amounts to 1,273.

Most NCAA revenue (81 percent projected for 2012-13) comes from media rights, mainly derived from a $\$ 10.8$ billion, 14-year agreement with CBS Sports and Turner Broadcasting for rights to the Division I Men's Basketball Championship. Most of the remaining revenue comes from NCAA championships, primarily ticket sales and some additional TV rights. The income is distributed to schools who participate in the tournament and others. The deeper a team progresses in the NCAA Basketball tournament, the greater the team's share of the revenue will be! Many schools rely heavily, if not exclusively, on the share of revenues to finance a significant portion of their entire athletic program.

During the 2010-2011 college football bowl season, the Bowl Championship Series (BCS) distributed over \$169 million, which was derived, in part, from a \$125 million ESPN media rights agreement. Individual intercollegiate athletic conferences were also negotiating and obtaining enormous individual media rights agreements, which was evidenced by the Southeastern Conference's fifteen-year, $\$ 2.5$ billion agreement with ESPN. As a result of the economic prosperity in intercollegiate athletics, coaches and administrators are receiving generous salaries and benefits. Duncan and McMillan (2013) reported that in 2011, 32 NCAA Football Bowl Subdivision (FBS) and 11 NCAA Division I men's basketball coaches earned more than $\$ 2$ million annually. As reported by Fram and Frampton (2012, p. 1003): "Each victory during the tournament earns schools and their co-conference members approximately $\$ 1.5$ million from the NCAA, and coaches' contracts regularly include six-figure performance bonuses rewarding tournament victories."

Interestingly, Arne Duncan (Secretary of Education) and Tom McMillan (former professional basketball player and member of the University System of Maryland Board of Regents) noted that while about two-thirds of basketball coaching contracts and three-fourths of football coaching contracts did include a bonus for academic performance, these contracts were "dwarfed" for athletic performance. "Academic incentives averaged $\$ 52,000$ per coach, while athletic incentives averaged \$600,000 per coach." (Duncan \& McMillan, 2013, p. 2C; salary and contract information may be found at http://Sports.USATODAY.com.).

There is also an equitable or fairness issue that needs to be addressed: Why should an organization with the enormous power of the NCAA be immune from considerations of fairness or equity in their dealings both with individual school members or athletes or, in the case of Coach Tarkanian, athletic department personnel? According to NCAA Bylaw 19.01.1 "an important consideration in imposing penalties is to provide fairness to uninvolved student-athletes, coaches, administrators, and other institutions." (NCAA Division I Manual, 2010, § 19.01.1). How can this "fairness" be assured in dealing between the NCAA and its member schools without assuring basic due process guarantees?

Josephine Potuto is the Richard H. Larson Professor of Constitutional Law at the University of Nebraska College of Law. Professor Potuto also serves as the University's Faculty Athletic Representative (FAR) at the University of Nebraska-Lincoln (UNL). Professor Potuto served for nine years on the NCAA Division I Committee on Infractions, two as vice chair and two as chair.

Professor Potuto has summarized the arguments for and against state actor status for the NCAA's regulation of intercollegiate athletics. (Potuto, 2012). Rather than focus on a traditional "black letter rule enunciation" of constitutional principles relating to private actors and due process, Professor Potuto focused on the "circumstances, equities, and consequences" of the argument.

The arguments for state actor status may be summarized as follows:

- $\quad$ "Even though most NCAA members are private, the NCAA nonetheless should be a state actor because the overwhelming majority of institutions in Division I are public. The NCAA should be a state actor because it is big, national, and powerful. It is the face of college athletics, and, for FBS institutions in particular, it effectively is "the only game in town."' [Doesn't this sound a lot like the rationale offered in Brentwood Academy?] 
- "The NCAA should be a state actor because its decisions have a substantial adverse impact on non-members, especially the student-athletes who compete at member institutions and the coaches who are employed by them; yet as non-members they have no role in adopting or changing NCAA bylaws and policies that affect them." (Potuto, 2012, pp. 5-6).

Professor Potuto then advances two primary, and related, arguments made by those who would hold the NCAA as a non-state actor, thus not subject to due process considerations:

- "The NCAA should not be a state actor because such status would upend the law governing private associations by permitting non-members to advance their agendas against the right of members of an association to chart their own course." (Potuto, 2010).

- "The NCAA should not be a state actor because such status would instigate regular, protracted, and often frivolous litigation against it that would thwart, if not subvert, NCAA efforts to maintain a level playing field among teams from competing member institutions and to advance core values. The impact would be most severe in lawsuits brought by student-athletes, even if the NCAA ultimately prevailed every time, as they likely would compete during the course of litigation." (Potuto, 2012, p. 6).

\section{Some Tentative Conclusions}

So, what is the better argument? What should the Supreme Court do if it is again confronted by a set of facts which closely or nearly resemble Tarkanian? Should not one of these "core values" be the requirement of "due process" when the NCAA deals with players, coaches, and administrative personnel? One persistent critic of the NCAA, N.Y Times writer Joe Nocera, frames the issue directly and persuasively:

"How can the N.C.A.A. blithely wreck careers without regard to due process or common fairness? How can it act so ruthlessly to enforce rules that are so petty? Why won't anybody stand up to these outrageous violations of American values and American justice?"

Nocera's comments were made specifically with reference to a case involving a University of Connecticut athlete, Ryan Boatright. Nocera (2012) noted that the NCAA had refused to offer any comments relating to the actions of its investigators. It essentially said that Connecticut, not the N.C.A.A., had declared Boatright ineligible- -which is, of course, technically true. However, reflecting on the realities expressed in Tarkanian, Nocera (2012) commented: "Schools declare athletes ineligible because if they don't, the N.C.A.A. will deprive them of scholarships, force them to forfeit games and prevent them from playing in postseason games. Most astonishing, an N.C.A.A. spokeswoman told me that the organization does not have the legal authority to compel cooperation from parents. Again, technically true: Its real weapon — the threat of destroying their sons' careers — is far more potent than any mere subpoena." In an article that described a dispute between the NCAA and yet another coach, Tim Cohane of SUNY Buffalo, NCAA critic Joe Nocera referred to the dreaded" show cause order. Nocera wrote: "Any school that wanted to hire Cohane as head coach would have had to explain its decision to the NCAA. Branded with that Scarlet "A", ..., Cohane's career as a college head coach was over." (Nocera, 2013).

In a noted sports blog, Mike Kueber (2012) notes that Nocera has also attacked the NCAA as a cartel, exercising enormous and unbridled power on college athletics and athletes, engaged in both collusion and price fixing, and compared it to OPEC. Isn't it time to hold the NCAA to account for its actions?

One solution would be to require some defined due process when the NCAA attempts to discipline a member institution or to require a member institution to take disciplinary action against one of its coaches, players, or administrative personnel involving possible termination or firing pursuant to findings made by the NCAA in its own investigative procedures. Very few critics of the NCAA would seriously want to apply due process to all facets of athletic regulations or competition rules. But where the NCAA has taken an action to deprive an individual of their livelihoods or property — or perhaps even of their athletic eligibility - fairness dictates the extension of minimum standards to due process rights to these cases. Clearly, the NCAA is the "only game in town" that really matters. The NCAA might wish to consult Judge Friendly for a primer on this topic!

\section{Appendix I}

Among the sanctions that the Committee may impose "against an institution" are:

"(1) Reprimand and censure;

"(2) Probation for one year;

"(3) Probation for more than one year; 
"(4) Ineligibility for one or more National Collegiate Championship events;

"(5) Ineligibility for invitational and postseason meets and tournaments;

"(6) Ineligibility for any television programs subject to the Association's control or administration;

"(7) Ineligibility of the member to vote or its personnel to serve on committees of the Association, or both;

"(8) Prohibition against an intercollegiate sports team or teams participating against outside competition for a specified period;

"(9) Prohibition against the recruitment of prospective student-athletes for a sport or sports for a specified period ...."

The most severe sanction the NCAA can bring against a member institution is commonly known as the "death penalty." The application of the "death penalty" involves the complete elimination of either a school's entire athletic program or a single sport for at least one year. As a practical matter, the NCAA reserves this penalty for "repeat violators" and has only applied it once in NCAA Division-I football history. In 1987 and 1988, the "death penalty" was applied to Southern Methodist University's football program for violations of the principals of amateurism and for providing "extra benefits" to student athletes. (Davis \& Malagrino, 2012, notes 33-35).

\section{Appendix II}

Division I Conferences:

- America East Conference

- Atlantic Coast Conference (ACC)

- Atlantic Sun Conference

- Atlantic 10 Conference (A-10)

- Big East Conference

- Big Sky Conference

- Big South Conference

- Big Ten Conference (Big Ten)

- Big 12 Conference (Big 12)

- Big West Conference

- Colonial Athletic Association (CAA)

- Conference USA (C-USA)

- Great West Conference

- Horizon League

- NCAA Independents

- Ivy League

- Metro Atlantic Athletic Conference (MAAC)
- Mid-American Conference (MAC)

- Mid-Eastern Athletic Conference (MEAC)

- Missouri Valley Conference (MVC or The Valley)

- Mountain Pacific Sports Federation (MPSF)

- Mountain West Conference (MW or MWC)

- Northeast Conference (NEC)

- Ohio Valley Conference (OVC)

- Pacific-12 Conference (Pac-12)

- Patriot League

- Renamed Big East Conference

- Southeastern Conference (SEC)

- Southern Conference (SoCon)

- Southland Conference

- Southwestern Athletic Conference (SWAC)

- The Summit League (The Summit)

- Sun Belt Conference (SBC)

- West Coast Conference (WCC)

- Western Athletic Conference (WAC)

\section{Division I FCS football-only conferences}

- Missouri Valley Football Conference

- Pioneer Football League

\section{Division I hockey-only conferences}

- Atlantic Hockey

- Central Collegiate Hockey Association (CCHA) - will disband after the 2012-13 season due to major conference realignment

- College Hockey America

- ECAC Hockey

- Hockey East

- National Collegiate Hockey Conference (NCHC) - future conference; set to begin play in 2013-14

- Western Collegiate Hockey Association (WCHA) 


\section{References}

Bianchi, M. (2010). Guardian of amateurism or legal defiant: the dichotomous nature of NCAA men's ice hockey regulation. Seton Hall Journal of Sports and Entertainment Law, 20, 165-203.

Campion, W. T. (2013). MCLE self-study: sports law- MCLE center for continuing education. Retrieved from http://www.cce-mcle.com/tests/ss6003.htm

Davis, C., \& Malagrino, D. O. (2012). Hold your fire: the injustice of NCAA sanctions on innocent student athletes. Virginia Sports \& Entertainment Law Journal, 11, 432-459.

Duncan, A., \& McMillan, T. (2013, March 24). Secretary of education: hit 'em in the wallet. USA Today, p. 2C.

Fram, N., \& Frampton, T. W. (2012). A Union of amateurs: a legal blueprint to reshape big-time college athletics. University of Buffalo Law Review, 60, 1003-1078.

Friendly, H. J. (1975). Some kind of hearing. University of Pennsylvania Law Review, 123, 1267-1295. http://dx.doi.org/10.2307/3311426

Hunter, R., \& Alexander-Becker, P. (2007). Is it time to revisit the doctrine of "state action" in the context of intercollegiate and interscholastic sports? Villanova University Sports \& Entertainment Law Journal, 14(2), 191-232.

Hunter, R., \& Lozada, H. R. (2010). A nomination of a supreme court justice: the incorporation doctrine revisited. Oklahoma City Law Review, 35, 365-385.

Katyal, S., \& Schultz. J. M. (2012). The unending search for the optimal infringement filter. Columbia Law Review, 83, 83-107.

Krotoszynski, R. J. (1995). Back to the briarpatch: an argument in favor of constitutional meta-analysis in state action determination. Michigan Law Review, 94, 302-334. http://dx.doi.org/10.2307/1289840.

Kueber, M. (2012, January 2). Nocera weighs in against the NCAA. Retrieved from http://mkueber001.wordpress.com/2012/01/02/nocera-weighs-in-against-the-ncaa/.

Major League Baseball Standard Player Contract. (2013). Retrieved from http://www.mlb.mlb.com/pa/pdf/cba_english.pdf

Model State Administrative Procedure Act. (1981). Section 4-201.

NCAA Division I Manual. (2010).

Nocera, J. (2012). Living in fear of the NCAA. Retrieved from http://www.nytimes.com/2012/01/24/opinion/nocera-living-in-fear-of-the-NCAA

Nocera, J. (2013, March 29). The coach who fought back. The New York Times. Retrieved from http://www.nytimes.com/2013/03/30/opinion/nocera-the-coach-who-fought-back.html

Potuto, J. (2012). NCAA as state actor controversy: much ado about nothing. Marquette Sports Law Review, 23, $1-44$.

Salary Database. (2013). Retrieved from http://www.Sports.USATODAY.com.

United States Constitution, Amendment XIV.

Website of the NCAA. (2013). Retrieved from http://www.ncaa.org.

\section{Cases Cited}

Adickes v. S.H. Kress \& Co., 398 U.S. 144 (1970)

Barrows v. Jackson, 346 U.S. 249 (1953)

Blum v. Yaretsky, 457 U.S. 991 (1982)

Brentwood Academy v. Tennessee Secondary School Athletic Association, 531 U.S. 288 (2001)

Burton v. Wilmington Parking Authority, 365 U.S. 715 (1961)

Civil Rights Cases, 109 U.S. 3 (1883)

Cleveland Board of Education v. Loudermill, 470 U.S. 532 (1984).

Dennis v. Sparks, 449 U.S. 24 (1980) 
Ex parte Virginia, 100 U.S. 339 (1879)

Hudgens v. NLRB, 424 U.S. 507 (1976)

Jackson v. Metropolitan Edison Co., 419 U.S. 345 (1974)

Lebron v. National Railroad Passenger Corp. (Amtrak), 513 U.S. 374 (1995)

Lombard v. Louisiana, 373 U.S. 267 (1963)

Lugar v. Edmondson Oil Co., 457 U.S. 922 (1982)

Marsh v. Alabama, 326 U.S. 501 (1946)

Moose Lodge v. Irvis, 407 U.S. 163 (1972)

National Collegiate Athletic Association v. Tarkanian, 488 U.S. 179 (1988)

Peterson v. City of Greenville, 373 U.S. 244 (1963)

Public Utilities Commission of the District of Columbia v. Pollak, 343 U.S. 451 (1952)

Reitman v. Mulkey, 387 U.S. 369 (1967)

Rendell-Baler v. Kohn, 457 U.S. 830 (1982)

Screws v. United States, 325 U.S. 91 (1945)

Shelley v. Kraemer, 334 U.S. 1 (1948)

Smith v. Allwright, 321 U.S. 649 (1944)

Tarkanian v. NCAA, 741 P.2d 1345 (1987), 488 U.S. 179 (1988)

Terry v. Adams, 345 U.S. 461 (1953)

\section{Copyrights}

Copyright for this article is retained by the author(s), with first publication rights granted to the journal.

This is an open-access article distributed under the terms and conditions of the Creative Commons Attribution license (http://creativecommons.org/licenses/by/3.0/). 